\title{
Serum concentration patterns of an LHRH agonist, gonadotrophins and sex steroids after subcutaneous, vaginal, rectal and nasal administration of the agonist to pregnant rats
}

\author{
I. Yamazaki \\ Biology Laboratories, Central Research Division, Takeda Chemical Industries Ltd, \\ 17-85, Jusohonmachi 2-Chome, Yodogawaku, Osaka 532, Japan
}

\begin{abstract}
Summary. A highly potent LHRH agonist, des-Gly ${ }^{10} \cdot\left[\mathrm{D}-\mathrm{Leu}^{6}\right]-\mathrm{LHRH}^{6}$-ethylamide (TAP-144), was administered by subcutaneous, vaginal, rectal and nasal routes to pregnant rats on Day 10. After subcutaneous administration, almost all the TAP-144 was rapidly absorbed and eliminated. After vaginal administration, the fraction of the dose that reached the systemic circulation, the $F$ value, was very high but the rate of absorption was very low; consequently there was a low peak level and persistence of serum level. After rectal administration, the $F$ value was very low and the rate of absorption was lower than that by the subcutaneous route; consequently the terminal phase half-life was between those of the subcutaneous and vaginal routes. After nasal administration, the $F$ value was also very low but the rate of absorption was enormously high and there was a rapid decrease in serum concentration. The pregnancyterminating effectiveness of the peptide by these routes of administration was not proportional to the transient high concentrations of the peptide but attributable to its persistence in the serum.

Serum LH and FSH concentrations after TAP-144 administration showed similar patterns with the different routes but the peak concentration of $\mathrm{LH}$ after vaginal administration was higher than that after other routes. Serum levels of progesterone and oestradiol-17 $\beta$ showed small peaks within $2 \mathrm{~h}$ after TAP-144 was administered by any route and fluctuated thereafter but the level dropped only in the rats given a dose of TAP-144 that was $100 \%$ effective in terminating pregnancy.
\end{abstract}

\section{Introduction}

A single administration of luteinizing hormone-releasing hormone (LHRH) and its agonists stimulates the pituitary to secrete gonadotrophins which, in turn, enhance the secretion of ovarian steroids. Long-term administration of large doses of these peptides paradoxically acts on the ovaries directly or indirectly to suppress secretion of the steroids (Belchetz, Plant, Nakai, Keogh \& Knobil, 1978; Kledzik, Cusan, Auclair, Kelly \& Labrie, 1978; Bex \& Corbin, 1979; Harwood, Clayton, Chen, Knox \& Catt, 1980; Jones \& Hsueh, 1980, 1981; Behrman, Preston \& Hall, 1980). These peptides reportedly antagonize the biological actions of ovarian steroids (Pedroza, VilchezMartinez, Coy, Arimura \& Schally, 1980; Sundaram et al., 1981). There have been many attempts to utilize the paradoxical effect of these peptides for application as contraceptives (Berquist, Nillius \& Wide, 1979) and treatment of hormone dependent cancer (Klijn \& de Jong, 1982; Borgmann, Hardt, Schmidt-Gollwitzer, Adenauer \& Nagel, 1982). 
Although clinical application of these peptides is highly promising, their potential may be restricted by difficulties involved in self-medication, except by the nasal route (Berquist et al., 1979; Klijn \& de Jong, 1982; Borgmann et al., 1982). A radioimmunoassay technique for a highly active LHRH agonist, des-Gly ${ }^{0}-\left[\right.$ D-Leu $\left.^{6}\right]-$ LHRH-ethylamide (TAP-144) showed that the serum concentration of this peptide, after vaginal administration, was lower but sustained for longer than that after subcutaneous administration to dioestrous rats (Yamazaki \& Okada, 1980). When this peptide was administered to rats on Day 10 , pregnancy was terminated most effectively after vaginal administration (Yamazaki, 1982b). These findings suggest that the prolonged duration of an effective concentration of these peptides is more important than a transient high concentration for the paradoxical effect. However, there is little documentation comparing the changes in blood concentrations of these peptides after they are administered by various routes. The studies reported here were designed to obtain such data.

\section{Materials and Methods}

Animals. Sprague-Dawley rats (Japan CLEA) aged 120-150 days (250-330 g) were fed a commercial diet (CE-2, Japan CLEA) and drinking water ad libitum, in an air-conditioned environment $\left(24 \pm 1^{\circ} \mathrm{C}, 50-60 \%\right.$ humidity) illuminated for $14 \mathrm{~h} /$ day from $07: 30$ to $21: 30 \mathrm{~h}$. Vaginal smears were examined each morning. Only rats regularly exhibiting two or more consecutive 4-day oestrous cycle were caged with fertile males on the evening of pro-oestrus. The next morning, if spermatozoa were present in the vagina, was considered to be Day 1 of pregnancy.

LHRH agonist. TAP-144 (lot 5-2) was synthesized in our Chemistry Laboratories (Fujino et al., 1974). The peptide, dehydrated for $5 \mathrm{~h}$ at $50^{\circ} \mathrm{C}$ under a reduced pressure before use, was dissolved in saline $(9 \mathrm{~g} \mathrm{NaCl} / 1)$ containing $0.1 \%$ bovine serum albumin (Wako Pure Chemical, Osaka, Japan), $20 \mathrm{U}$ Trasylol (Bayer, Leverkusen, West Germany)/ml and $0.01 \mathrm{~N}-\mathrm{HCl}$. In some experiments, a surfactant, polyoxyethylene-9-laulyl ether (BL-9, Nikko Chemical, Tokyo, Japan) of $10 \%$ concentration, was added to the solution to enhance the rectal and nasal absorption of TAP-144 (Yamazaki, 1982b).

Procedure of peptide administration and serum collection. The peptide was administered on Day 10 of pregnancy. For subcutaneous administration, the peptide solution $(200 \mu \mathrm{l} / 100 \mathrm{~g}$ body wt) was injected into the nape of the neck. For vaginal and rectal administration, a small cotton ball of about $12 \mathrm{mg}$ was saturated with the peptide solution $(20 \mu \mathrm{l} / 100 \mathrm{~g}$ body wt). This ball, a rubber stopper, and another cotton ball were inserted into the vagina or rectum which was then sealed with a surgical adhesive. For nasal administration, $10 \mu \mathrm{l} / 100 \mathrm{~g}$ body weight of the peptide solution was placed along the nasal wall with a micropipette.

At 5, 10, 20 and $40 \mathrm{~min}$, and 1, 2,3, 4, 5, 6, 8, 12,24 and $48 \mathrm{~h}$ after the administration, 7 rats in one group were anaesthetized with ether and exsanguinated from the abdominal aorta. The separated serum was stored at $-20^{\circ} \mathrm{C}$ until hormone assay.

Hormone assays. Serum TAP-144 was measured using the radioimmunoassay method according to the double-antibody technique reported previously (Yamazaki \& Okada, 1980). The reference preparation used for standards was TAP-144 lot 5-2. The antiserum used in the assay was antirabbit TAP-144 No. 67-15. LH, FSH, TRH, LHRH and the fragment of TA-144 (pyroGlu-HisTrp-Ser-Tyr-D-Leu-OH) did not practically cross-react with this antiserum $(<0.4 \%)$. The assay sensitivity was $20 \mathrm{pg}$ and intra- and inter-assay coefficients of variation were $7 \cdot 1$ and $15 \cdot 2 \%$, respectively.

Serum LH and FSH were measured with radioimmunoassay kits supplied by the Rat Pituitary Program, NIAMDD, NIH, Bethesda, Maryland, U.S.A., according to the double-antibody technique of Monroe, Parlow \& Midgley (1968) and Midgley (1968). The assay results were expressed in terms of NIAMDD-Rat-LH-RP-1 and NIAMDD-Rat-FSH-RP-1, respectively. The 
antisera used were anti-rat LH S-3 and anti-rat FSH S-10 and assay sensitivities were 4 and $10 \mathrm{ng}$, respectively. Intra- and inter-assay coefficients of variation were 2.8 and $11.0 \%$ for LH and $4 \cdot 1$ and $16 \cdot 1 \%$ for FSH, respectively.

Serum progesterone was measured using a commercial radioimmunoassay kit (Daiichi Radioisotope Labs, Japan) (Matsumoto, Nakamura, Tanabe \& Iizuka, 1977). The bound and free hormones were separated using polyethylene glycol. The assay sensitivity was $31.3 \mathrm{pg}$ and intraand inter-assay coefficients of variation were 13.1 and $17.9 \%$, respectively. The cross-reaction of the antiserum with other steroids was $<1 \%$, except for $11 \alpha$-hydroxyprogesterone $(65 \%)$ and desoxycorticosterone $(2 \cdot 9 \%)$.

Serum oestradiol-17 $7 \beta$ was also measured using a commercial radioimmunoassay kit (Daiichi Radioisotope Labs) (Uemura, Kooguchi, Shirasu \& Shiojima, 1977) according to the doubleantibody technique. The assay sensitivity was $6.25 \mathrm{pg}$ and intra- and inter-assay coefficients of variation were 5.0 and $11.8 \%$, respectively. The cross-reactions of this antiserum with oestrone $(4 \cdot 1 \%)$, oestriol $(1.9 \%)$, testosterone $(0 \cdot 2 \%)$, progesterone $(0 \%)$ and $17 \alpha$-hydroxyprogesterone $(0 \%)$ were fairly low.

Data analysis. The half-life of serum TAP-144 concentration was determined by linear regression by least square analysis. The absorption rate constant, the volume of distribution at steady state, the fraction of the dose that reached the systemic circulation (F) and the elimination rate constant were calculated by simultaneous non-linear least squares fitting of the time course data to one compartment model using the program MULTI (Yamaoka, Tanigawara, Nakagawa \& Uno, 1981). The area under the serum concentration-time curve was calculated by using the trapezoidal rule (Ritschell, 1980). The statistical significance between means was determined by Dunnett's test (1955).

\section{Results}

As shown in Text-fig. 1 and Table 1, there were considerable differences in the serum levels of TAP-144 after it was administered by the different routes. The fraction of the dose that reached the

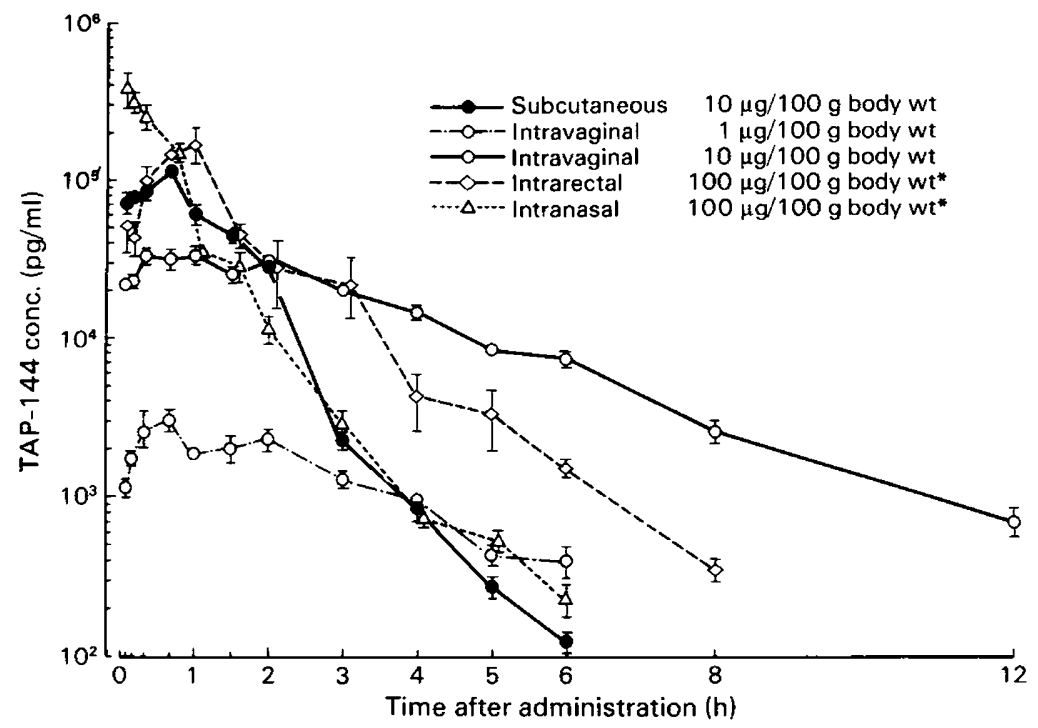

Text-fig. 1. Changes in serum concentration of TAP-144 after a single subcutaneous, vaginal, rectal and nasal administration to pregnant rats on Day 10. Each point represents the mean \pm s.e.m. for 7 rats. ${ }^{*}$ BL- 9 was added to the solution at a concentration of $10 \%$. 
Table 1. Measures of serum values and pregnancy termination of TAP-144 administered $(\mu \mathrm{g} / 100 \mathrm{~g}$ body wt) by different routes to pregnant rats on Day 10

\begin{tabular}{|c|c|c|c|c|c|}
\hline & \multirow{2}{*}{$\frac{\text { Subcutaneous }}{10 \mu \mathrm{g}}$} & \multicolumn{2}{|c|}{ Intravaginal } & \multirow{2}{*}{$\frac{\text { Intrarectal }}{100 \mu \mathrm{g}^{*}}$} & \multirow{2}{*}{$\frac{\text { Intranasal }}{100 \mu \mathrm{g}^{*}}$} \\
\hline & & $I \mu \mathrm{g}$ & $10 \mu \mathrm{g}$ & & \\
\hline Peak concentration ( $\mathrm{ng} / \mathrm{ml})$ & $110 \cdot 3$ & 3.0 & $33 \cdot 3$ & $165 \cdot 1$ & 379.9 \\
\hline Peak time (min) & 40 & 40 & 60 & 60 & 5 \\
\hline $\begin{array}{l}\text { Area under the curve } \\
\text { from } 0 \text { to } 48 \mathrm{~h}\left(\mathrm{ng} \cdot \mathrm{h}^{-1} / \mathrm{ml}\right)\end{array}$ & $145 \cdot 8$ & 8.7 & 140.0 & $227 \cdot 3$ & 223.9 \\
\hline $\begin{array}{l}\text { Terminal phase half-life } \\
\text { (min) }\end{array}$ & $32 \cdot 0$ & $90 \cdot 6$ & $109 \cdot 8$ & $55 \cdot 5$ & $43 \cdot 7$ \\
\hline $\mathrm{F}+$ & 0.941 & 0.560 & 0.846 & $0 \cdot 157$ & $0 \cdot 164$ \\
\hline $\begin{array}{l}\text { Absorption rate constant } \\
(/ \mathrm{h})\end{array}$ & $2 \cdot 574$ & 0.600 & 0.487 & $1 \cdot 382$ & $\infty$ \\
\hline \multirow{2}{*}{$\begin{array}{l}\text { Percentage of pregnancy } \\
\text { termination by } \\
\text { once a day dose } \neq\end{array}$} & 0 & 40 & 100 & 17 & 0 \\
\hline & (948) & \multicolumn{2}{|c|}{$(1 \cdot 2)$} & (898) & $(>2000)$ \\
\hline \multirow{2}{*}{$\begin{array}{l}\text { Percentage of pregnancy } \\
\text { termination by } \\
\text { twice a day dose } \neq\end{array}$} & 100 & 100 & 100 & 100 & 100 \\
\hline & $(0.032)$ & \multicolumn{2}{|c|}{$(0.054)$} & $(8 \cdot 69)$ & $(3 \cdot 19)$ \\
\hline
\end{tabular}

Figures in parentheses represent the $50 \%$ effective dose $(\mu \mathrm{g} / 100 \mathrm{~g}$ body weight/time) of TAP- 144 .

* BL-9 was added to the solution of TAP-144 at a concentration of $10 \%$.

$\dagger$ The fraction of the dose that reaches the systemic circulation.

$\ddagger$ The data are from Yamazaki (1982b).

systemic circulation, the $F$ value, after subcutaneous administration was calculated to be 0.941 in non-pregnant female rats by comparing the areas under the time-concentration curves after intravenous and subcutaneous administrations determined in a previous report (Yamazaki \& Okada, 1980). As the $\mathrm{F}$ value after subcutaneous administration was thought not to be greatly different between non-pregnant and pregnant rats, it was presumed to be 0.941 for the present study. The volume of distribution at steady state was calculated as $37.2 \mathrm{ml} / 100 \mathrm{~g}$ body weight and the elimination rate constant as $1.861 / \mathrm{h}$. These two values are constant as long as the blood flow rates through the disposing organs and the binding of TAP-144 to serum protein are not different by different routes of administration. After vaginal administration, the $F$ value was much higher than that after nasal and rectal routes, and the rate of absorption was lower than that after the other 3 routes. Thus, in comparison to the other routes, there was a lower peak level and persistence of serum values. After rectal administration, the $F$ value was very low and the rate of absorption was lower than that by the subcutaneous route; consequently the terminal phase half-life was between those obtained for the subcutaneous and vaginal routes. After nasal administration, the $F$ value was also very low but the rate of absorption was enormously high; consequently there was a rapid decrease in serum concentration.

Regardless of the route of TAP-144 administration, serum LH concentrations transiently rose to peak at 90 or $120 \mathrm{~min}$ then decreased gradually to the pretreatment level within $24 \mathrm{~h}$ (Text-fig. 2). However, the peak levels after vaginal administration were higher than those after the other routes of administration. Serum FSH levels also rose transiently regardless of the route of administration; the levels peaked at $120 \mathrm{~min}$, subsided to the pretreatment level within $12 \mathrm{~h}$, and then rose again slightly at 24 and $48 \mathrm{~h}$.

Serum LH and FSH concentrations declined to about the same low level by $8 \mathrm{~h}$ after the TAP144 administration regardless of the route. However, the serum level of TAP-144 after vaginal administration at a dose of $10 \mu \mathrm{g} / 100 \mathrm{~g}$ body weight was comparable to that at $2,3,5$ and $3 \mathrm{~h}$ after administration by the vaginal route at $1 \mu \mathrm{g}$, by the subcutaneous route at $10 \mu \mathrm{g}$, by the rectal route at $100 \mu \mathrm{g}$ and by the nasal route at $100 \mu \mathrm{g} / 100 \mathrm{~g}$ body weight, respectively, at which times serum LH and FSH levels were significantly higher than those at $8 \mathrm{~h}$ after vaginal administration at a dose of $10 \mu \mathrm{g} / 100 \mathrm{~g}$ body weight (Table 2 ). 

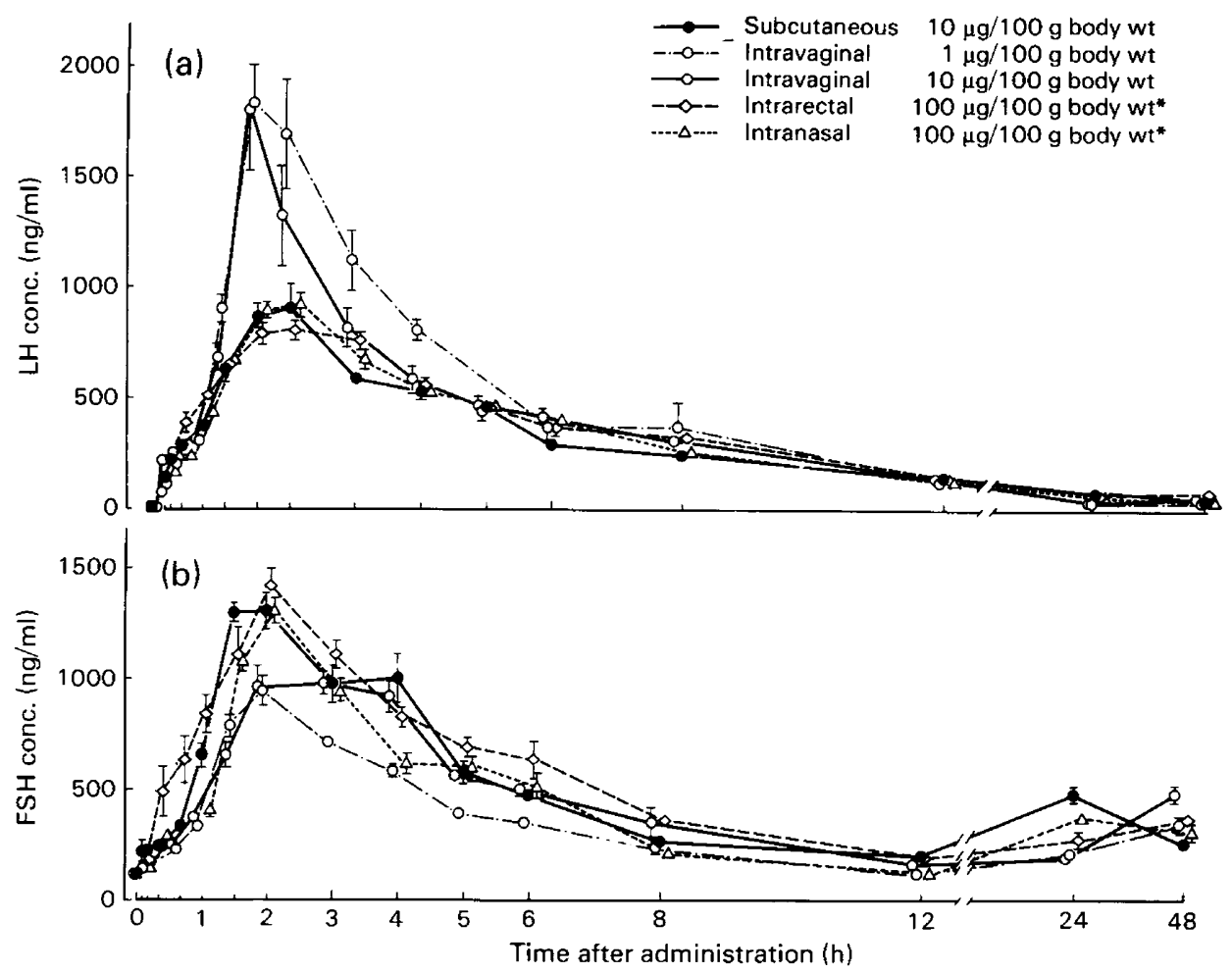

Text-fig. 2. Changes in serum LH (a) and FSH (b) concentrations after a single subcutaneous, vaginal, rectal and nasal administration of TAP-144 to pregnant rats on Day 10. Each point represents the mean \pm s.e.m. for 7 rats. ${ }^{*}$ BL- 9 was added to the solution of TAP-144 at a concentration of $10 \%$, Serum concentration in the control rats.

Table 2. Comparison of the serum concentrations of TAP-144, LH and FSH after a single administration of TAP-144 by different routes at times when the serum concentration of TAP-144 was roughly the same as that $8 \mathrm{~h}$ after vaginal administration at a dose of $1 \mu \mathrm{g} / 100 \mathrm{~g}$ body weight

\begin{tabular}{ccccccc}
\hline Group & $\begin{array}{c}\text { Dose of TAP-144 } \\
(\mu \mathrm{g} / 100 \mathrm{~g} \text { body wt) }\end{array}$ & $\begin{array}{c}\text { Route of } \\
\text { administration }\end{array}$ & $\begin{array}{c}\text { Time after } \\
\text { administration }(\mathrm{h})\end{array}$ & $\begin{array}{c}\text { TAP-144 } \\
(\mathrm{pg} / \mathrm{ml})\end{array}$ & $\begin{array}{c}\mathrm{LH} \\
(\mathrm{ng} / \mathrm{ml})\end{array}$ & $\begin{array}{c}\text { FSH } \\
(\mathrm{ng} / \mathrm{ml})\end{array}$ \\
\hline 1 & 10 & Intravaginal & 8 & $2602 \pm 402$ & $307 \pm 18$ & $349 \pm 64$ \\
2 & 1 & Intravaginal & 2 & $2306 \pm 338$ & $1685 \pm 253^{*}$ & $943 \pm 71^{*}$ \\
3 & 10 & Subcutaneous & 3 & $2276 \pm 288$ & $580 \pm 27^{*}$ & $971 \pm 86^{*}$ \\
4 & $100 \dagger$ & Intrarectal & 5 & $3380 \pm 1417$ & $454 \pm 11$ & $684 \pm 42^{*}$ \\
5 & $100 \dagger$ & Intranasal & 3 & $2895 \pm 520$ & $663 \pm 40^{*}$ & $937 \pm 43^{*}$ \\
\hline
\end{tabular}

Values are mean \pm s.e.m. for 7 rats.

* Significantly different from Group $1(P<0.05$, Dunnett's test $)$.

$\uparrow$ BL-9 was added to the solution of TAP-144 at a concentration of $10 \%$.

Regardless of the route of administration of TAP-144, the serum progesterone levels showed a small peak within $2 \mathrm{~h}$ and fluctuated thereafter (not shown). After vaginal administration of $10 \mu \mathrm{g}$ TAP-144/100 g body weight, progesterone levels were significantly lower than the pretreatment level by $5 \mathrm{~h}$ and remained relatively constant for $48 \mathrm{~h}$ except for a definite peak at $12 \mathrm{~h}$. After rectal administration, the progesterone level was lowered significantly at $3 \mathrm{~h}$, increased thereafter, and decreased again at 24 and $48 \mathrm{~h}$. Serum progesterone levels after subcutaneous or nasal administration were not significantly lower than pretreatment values. Shortly after the administration of TAP-144, regardless of the route, serum levels of oestradiol-17 7 also showed a 
small peak and fluctuated thereafter, but there was no characteristic pattern for a specific route of administration. The serum oestradiol-17 $\beta$ level was significantly lower than the pretreatment level only at $24 \mathrm{~h}$ after vaginal administration $(10 \mu \mathrm{g} / 100 \mathrm{~g}$ body $w \mathrm{t})$. The characteristic patterns in progesterone and oestradiol- $17 \beta$ levels were clearly reflected by the area under the timeconcentration curve of these sex hormones (Table 3 ).

Table 3. The area under the time-concentration curve (ng.h/ml) from 0 to $48 \mathrm{~h}$ for serum concentrations of progesterone and oestradiol-17 $\beta$ after a single administration of TAP-144 $(\mu \mathrm{g} / 100 \mathrm{~g}$ body wt) by different routes to pregnant rats on Day 10

\begin{tabular}{|c|c|c|c|c|c|}
\hline & \multirow{2}{*}{$\frac{\text { Subcutaneous }}{10 \mu \mathrm{g}}$} & \multicolumn{2}{|c|}{ Intravaginal } & \multirow{2}{*}{$\frac{\text { Intrarectal }}{100 \mu \mathrm{g}^{*}}$} & \multirow{2}{*}{$\begin{array}{c}\text { Intranasal } \\
100 \mu \mathrm{g}^{*}\end{array}$} \\
\hline & & $1 \mu \mathrm{g}$ & $10 \mu \mathrm{g}$ & & \\
\hline $\begin{array}{l}\text { Progesterone } \\
\text { Oestradiol-17 }\end{array}$ & $\begin{array}{l}5824 \pm 228 \\
1125 \pm 62\end{array}$ & $\begin{array}{c}4611 \pm 319 \\
847 \pm 53\end{array}$ & $\begin{array}{c}3265 \pm 237 \\
716 \pm 37\end{array}$ & $\begin{array}{l}4552 \pm 161 \\
1278 \pm 36\end{array}$ & $\begin{array}{c}5311 \pm 135 \\
875 \pm 42\end{array}$ \\
\hline
\end{tabular}

Values are mean \pm s.e.m. for 7 rats.

* BL-9 was added to the solution of TAP-144 at a concentration of $10 \%$.

\section{Discussion}

The time-concentration curves of TAP-144 after vaginal administration in doses of 1 and $10 \mu \mathrm{g} / 100$ $\mathrm{g}$ body weight to pregnant rats on Day 10 had much the same half-life and peak time; the peak concentrations were dose-dependent. The curves after intraperitoneal administration in doses of $0 \cdot 01,0 \cdot 1,1$ and $10 \mu \mathrm{g} / 100 \mathrm{~g}$ body weight to dioestrous rats also had about the same half-life and peak time, and dose-dependent peak concentrations (Yamazaki \& Okada, 1980). These observations suggest that the curves after the administration of TAP-144 by other routes may each have a characteristic half-life and peak time, and dose-dependent peak concentrations.

The present observation clearly shows the characteristic time-course profiles of the serum TAP144 concentration after subcutaneous, vaginal, rectal and nasal administration in pregnant rats. The absorption rate constants after vaginal and rectal administration were lower than the elimination rate constant, that is, these situations are flip-flop (Gibaldi \& Perrier, 1975). The terminal phase half-life for these routes reflects the absorption phase. On the other hand, the absorption rate constants after subcutaneous and nasal administration were greater than the elimination rate constant; the terminal phase half-life reflects the elimination phase.

The doses of TAP-144 used in the present study $(10,1,100$ and $100 \mu \mathrm{g} / 100 \mathrm{~g}$ body wt for the subcutaneous, vaginal, rectal and nasal routes, respectively) were selected as the $100 \%$ effective doses for pregnancy termination when administered at two separate times $8 \mathrm{~h}$ apart to pregnant rats on Day 10 of pregnancy, although a single administration of these doses of the peptide led to 0,40 , 17 and $0 \%$, respectively, failure of pregnancy (Yamazaki, 1982b). The effectiveness after a single vaginal administration of $10 \mu \mathrm{g} / 100 \mathrm{~g}$ body weight was $100 \%$. The pregnancy-terminating effectiveness of the peptide by different routes of administration was not proportional to the transient high concentration of the peptide but did parallel the persistence of serum values. It can therefore be concluded that the longer the peptide remains over the threshold concentration, the more effective it is for pregnancy termination. When compared with a single administration, the twice-a-day administration of TAP-144 by the subcutaneous, rectal and nasal routes, with which serum concentration of TAP-144 declined rapidly, induced a greater increment in the pregnancyterminating effectiveness than was observed when the vaginal route was used (Yamazaki, 1982b). This observation may be related to the finding that the duration of effective concentration of the peptide was increased with two administrations by these routes.

The decrease in serum levels of progesterone and oestradiol-17 $\beta$, essential steroids for the maintenance of pregnancy, did not always parallel the pregnancy-terminating effectiveness 
obtained by different routes of administration. The vaginal administration of $10 \mu \mathrm{g}$ TAP-144/100 g body weight, a dose that terminated pregnancy completely, led to a decrease in progesterone levels but doses and routes that did not affect progesterone levels gave $0-40 \%$ termination of pregnancy (Yamazaki, 1982b). The decreases in serum concentrations of progesterone and oestradiol-17 $\beta$ at $24 \mathrm{~h}$ after vaginal administration of a dose of $10 \mu \mathrm{g}$ TAP-144/100 $\mathrm{g}$ body weight were in accord with findings reported previously (Yamazaki, 1982a). The reason that the effectiveness of TAP-144 in terminating pregnancy did not always parallel its inhibitory action upon progesterone secretion is unclear. However, this peptide might act directly on the uterus to antagonize the biological actions of ovarian steroids as reported by Pedroza et al. (1980) and Sundaram et al. (1981). Another possibility is that this peptide might change the balance of progesterone and oestrogen secretion, which is important for the maintenance of pregnancy as reported earlier (Yamazaki \& Nakayama, 1970).

The serum level of $\mathrm{LH}$ after the administration of TAP-144 by different routes showed changes similar to those reported previously (Yamazaki \& Okada, 1980) but the peak level after vaginal administration of the peptide was higher than that seen with other routes. The ability of the peptide to stimulate the secretion of LH by the pituitary cells might be related to the constancy of the peptide concentration around the cells.

Serum FSH levels had slight but distinct second increases at 24 and $48 \mathrm{~h}$ after the administration of TAP-144 by all routes. This second peak probably corresponds to that reported for non-pregnant rats (Sasamoto, Harada \& Taya, 1979) as suggested previously (Yamazaki, 1982a).

Although the serum level of TAP-144 at $8 \mathrm{~h}$ after vaginal administration in a dose of $10 \mu \mathrm{g} / 100 \mathrm{~g}$ body weight was the same as that at 2 or $3 \mathrm{~h}$ after its administration in doses of 1,10 and $100 \mu \mathrm{g} / 100$ g body weight by the vaginal, subcutaneous and nasal routes, respectively, serum LH and FSH levels at $8 \mathrm{~h}$ after administration were decreased to a greater extent than at 2 or $3 \mathrm{~h}$ (Table 2). This result was in accord with the previous observation (Yamazaki \& Okada, 1980). This phenomenon suggests that desensitization of the pituitary cells to the peptide occurs during this period, because otherwise an LHRH analogue such as TAP-144 at the same blood concentration must induce the release of LH and FSH in the same amounts and their pituitary pools are known to be very large.

I thank H. Nakagawa and M. Kinoshita for technical assistance; Dr H. Okada, Dr Y. Igari and Dr Y. Tanigawara for comments on the pharmacokinetic analysis; Dr K. Kikuchi, M. Ohara and Dr J. R. Miller for comments on the manuscript; and the National Institute of Arthritis and Metabolic Diseases for supplying the radioimmunoassay kits for rat- $\mathrm{LH}$ and rat-FSH.

\section{References}

Behrman, H.R., Preston, S.L. \& Hall, A.K. (1980) Cellular mechanism of the antigonadotropic action of luteinizing hormone-releasing hormone in the corpus luteum. Endocrinology 107, 656-664.

Belchetz, P.E., Plant, T.M., Nakai, Y., Keogh, E.J. \& Knobil, E. (1978) Hypophysial responses to continuous and intermittent delivery of hypothalamic gonadotropin-releasing hormone. Science, N.Y. 202, 631-632.

Berquist, C., Nillius, S.J. \& Wide, L. (1979) Intranasal gonadotrophin-releasing hormone agonist as a contraceptive agent. Lancet 2, 215-217.

Bex, F.J. \& Corbin, A. (1979) Mechanism of the postcoital contraceptive effect of luteinizing hormone-releasing hormone: ovarian luteinizing hormone receptor interactions. Endocrinology 105, 139145.
Borgmann, V., Hardt, w., Schmidt-Gollwitzer, M., Adenauer, H. \& Nagel, R. (1982) Sustained suppression of testosterone production by the luteinizinghormone-releasing hormone agonist buserelin in patients with advanced prostate carcinoma. A new therapeutic approach? Lancet 1, 1097-1099.

Dunnett, C.W. (1955) A multiple comparison procedure for comparing several treatments with a control. $J$. Am. statist. Assoc. 50, 1096-1121.

Fujino, M., Fukuda, T., Shinagawa, S., Kobayashi, S., Yamazaki, I., Nakayama, R., Seely, J.H., White, W.F. \& Rippel, R.H. (1974) Synthetic analog of luteinizing hormone releasing hormone (LH-RH) substituted in position 6 and 10. Biochem. biophys. Res. Commun. 60, 406-413.

Gibaldi, M. \& Perrier, D. (1975) Pharmacokinetics. In Drugs and the Pharmaceutical Sciences, Vol. 1, pp. 
1-43. Ed. J. Swarbrick. Mercel Dekker, Inc., New York.

Harwood, J.P., Clayton, R.N., Chen, T.T., Knox, G. \& Catt, K.J. (1980) Ovarian gonadotropin-releasing hormone receptors. II. Regulation and effects of ovarian development. Endocrinology 107, 414 421.

Jones, P.B.C. \& Hsueh, A.J.W. (1980) Direct inhibitory effect of gonadotropin-releasing hormone upon luteal luteinizing hormone receptor and steroidogenesis in hypophysectomized rats. Endocrinology 107, 19301936.

Jones, P.B.C. \& Hsueh, A.J.W. (1981) Direct stimulation of ovarian progesterone metabolizing enzyme by gonadotropin-releasing hormone in cultured granulosa cells. J. biol. Chem. 256, 1248-1254.

Kledzik, G.S., Cusan, L., Auclair, C., Kelly, P.A. \& Labrie, F. (1978) Inhibitory effect of a luteinizing hormone ( $\mathrm{LH}$ )-releasing hormone agonist on rat ovarian LH and follicle-stimulating hormone receptor levels during pregnancy. Fert. Steril. 29, 560-564.

Klijn, J.M.G. \& de Jong, F.H. (1982) Treatment with a luteinizing-hormone-releasing-hormone analogue (buserelin) in premenopausal patients with metastatic breast cancer. Lancet 1, 1213-1216.

Matsumoto, S., Nakamura, Y., Tanabe, K. \& Iizuka, R. (1977) Basic evaluation and clinical application of ${ }^{125}$ I-progesterone RIA kit. Jpn. J. Fert. Steril. 22, 143-149. [In Japanese, abstract in English.]

Midgley, A.R., Jr (1968) Radioimmunoassay for human follicle-stimulating hormone. J. clin. Endocr. Metab. 27, 295-299.

Monroe, S.E., Parlow, A.F. \& Midgley, A.R., Jr (1968) Radioimmunoassay for rat luteinizing hormone. Endocrinology 83, 1004-1012.

Pedroza, E., Vilchez-Martinez, J.A., Coy, D.H., Arimura, A. \& Schally, A.V. (1980) Reduction of LH-RH pituitary and estradiol uterine binding sites by a superactive analog of luteinizing hormone-releasing hormone. Biochem. biophys. Res. Commun. 95, 10561062 .
Ritschell, W.A. (1980) Area under the blood level curve. In Handbook of Basic Pharmacokinetics, 2nd edn, pp. 274-283. Hamilton, Illinois.

Sasamoto, S., Harada, S. \& Taya, K. (1979) Prolonged release by dioestrous rats of follicle-stimulating hormone during the period of ovulation induced by luteinizing hormone releasing hormone. J. Endocr. 81, 109-118.

Sundaram, K., Cao, Y.-Q., Wang, N.-G., Bardin, C.W., Rivier, J. \& Vale, W. (1981) Inhibition of the action of sex steroids by gonadotropin releasing hormone (GnRH) agonists: a new biological effect. Life Sci. 28, 83-88.

Uemura, T., Kooguchi, J., Shirasu, K. \& Shiojima, Y. (1977) Comparison between estradiol-125I kit method and estradiol ${ }^{-3} \mathrm{H}$ radioimmunoassay method in serum estradiol levels obtained. Jpn. J. Fert. Steril. 22, 293-301. [In Japanese, Abstract in English.]

Yamaoka, K., Tanigawara, Y., Nakagawa, T. \& Uno, T. (1981) A pharmacokinetic analysis program (MULTI) for microcomputer. J. pharm. Dyn. 4, 879885.

Yamazaki, I. (1982a) Pregnancy terminating effect of a highly active LH-RH agonist by vaginal application in rats. Endocrinol. jap. 29, 197-207.

Yamazaki, I. (1982b) Differences in the pregnancyterminating effectiveness of an LH-RH analogue by subcutaneous, vaginal, rectal, and nasal routes in rats. Endocrinol. jap. 29, 415-421.

Yamazaki, I. \& Nakayama, R. (1970) Maintenance of pregnancy in ovariectomized rats with progesterone, $\Delta^{6}$-retroprogesterone, TSP-13 (21-methyl-17 $\alpha$-acetoxy-pregn-4-ene-3,20,21-trione) and norethynodrel. J. Takeda Res. Lab. 29, 450-461.

Yamazaki, I. \& Okada, H. (1980) A radioimmunoassay for a highly active luteinizing hormone-releasing hormone analogue and relation between the serum level of the anatogue and that of gonadotropin. Endocrinol. jap. 27, 593-605.

Received 16 January 1984 